\title{
Editorial / Editörden
}

\section{Malign plevral efüzyonda yaklaşım tarzı nasıl olmalıdır?}

\section{Berkant Özpolat}

Kırıkkale Üniversitesi Tıp Fakültesi, Göğüs Cerrahisi AD, Kırıkkale, TÜRKIYE

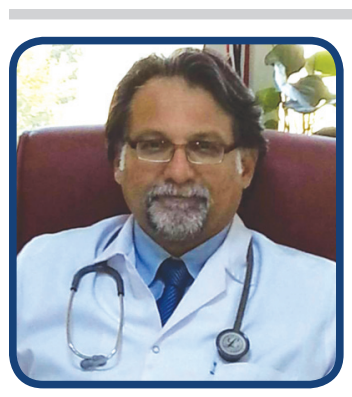

Semptomatik malign plevral efüzyon (MPE) geç dönem kanser olgularında ortak bir klinik sorundur. Her yıl yaklaşık 200.000 plevral efüzyon tanısı konan USA'da en sık malign efüzyon nedeni erkeklerde akciğer kanseri ve kadınlarda meme kanseri olarak bildirilmiştir [1].

Turkish Journal of Clinics and Laboratory'nin bu sayısında Yazkan'ın literatür derlemesinde malign plevral efüzyonların etiyolojisi, patofizyolojisi ve tedavisi sunulmaktadır. Tedavi yaklaşımını belirleyen etmenler arasında hastanın genel durumu, semptomları ve sağkalım süresi önemli yer teşkil eder. MPE'un hastalığın geç döneminde ortaya çıkması ve hastada kısıtlı bir yaşam beklentisi olması, uygun tedavi seçiminde fayda - risk dengesinin gözetilmesini gerektirir [2].

MPE'na yaklaşımın ilk basamağı torasentez olmalıdır. Teşhisin konulması ve semptomların gidermesi yanında akciğerin ekspansiyonu açısından ileriki yöntemlerin uygulanmasında yol göstericidir. Ancak 30 gün içinde MPE tekrar edeceğinden yaşam beklentisi birkaç hafta olan, terminal dönem olgularda uygulanmalıdır. İnterkostal tüp drenajı uygulanması ve sklerozan madde verilmesi en sık uygulanan yöntemdir. Uzun bir hospitalizasyon dönemi gerekeceği ve sklerozan maddeye bağlı komplikasyonlar görülebileceğinden, dikkatli bir değerlendirme gerektirir. Torakoskopi, biyopsi alınabilmesi, lokülasyonların giderilerek tam bir drenajın sağlanması ve aynı anda plörodez uygulanabilmesi nedeniyle, performans durumu iyi olan olgularda tercih edilen yöntem olmalıdır [3]. Kalıcı plevral kateter kullanımı diğer bir popüler yaklaşım yöntemidir. Özellikle tuzaklanmış akciğer saptanan ve plörodez planlanamayan, nüks görülen semptomatik olgularda önerilmektedir [4].

PubMed taramasında, sistofiks kateter kullanılarak plevral efüzyonun drene edilmesinin birkaç çalışma ile sınırlı olduğu dikkat çekmektedir [5,6]. Bu sayıda Akkaş ve ark plevral efüzyon drenajında literatürde nadiren raporlanmış bu yöntemi sunmaktalar [7]. 14 F sistofiks kateter uygulanan 11'i malign etiyolojiye sahip 59 olgunun analizi yapılmaktadır. Cerrahi enstümantasyon gerektirmemesi nedeniyle kolay ve hızlı uygulanması, daha az ağrıya neden olması, plörodez için uygun olması önemli noktalar olarak belirtilmektedir. Kliniğimizde de son yıllarda uygulanmakta olan bu yöntemin önceki dönemlerde $32 F^{\prime}$ e kadar uygulanmakta olan toraks drenleri ile benzer etkinlikte olduğu ve daha az rahatsızlık verdiği görülmektedir.

Sklerozan ajan seçiminde güvenlik, etki, ulaşılabilirlik, uygulama kolaylığı, uygulama sayısı ve maliyet önemli unsurlardır. Torakoskopik olarak uygulanan talk plöredezin başarısı \%96 olarak belirtilmekte ve akut pnömoni ve ARDS benzeri ciddi komplikasyonlardan kaçınılması amacıyla büyük partiküllü olanların tercih edilmesi ve atomizer ile uygulanması önerilmektedir [8,9].

Sonuç olarak MPE'da kateter ve talk plörodez semptomatik hastalarda kullanılmalıdır. Talk kullanımında büyük partiküllü olanlar ve yöntem olarak torakoskopik insuflasyon önerilir.

\section{References}

1. Light RW. Pleural diseases. 5th ed. Baltimore: Lippincot, Williams \& Wilkins; 2007.

2. Yazkan R. Malign plevral efüzyon. Turk J Clin Lab 2016; 7: 19-22.

3. Li Xiao, Ferguson MK. Optimal management of symptomatic malignant effusion. In MK Ferguson (ed.). Difficult Decisions in Thoracic Surgery. An Evidence-based approach 1. Springer-Verlag London. 2014. p. 635-645.

4. Suziki K, Servais EL, Rizk NP et al. Palliation and pleurodesis in malignant pleural effusion: the role for tunelled pleural catheters. J Thorac Oncol 2011; 6: 762-7.

5. Kılıc D, Fındıkcıoglu A, Hatipoglu A. Description of a new technique: management of pleural effusion with a cystofix catheter. Respirology 2007; 12: 288-90.

6. Clemetsen P, Evald T, Grode G, Hansen M, Krag Jacobsen G, Faurschou P. Treatment of malignant pleural effusion: pleurodesis using a small percutaneous catheter. A prospective randomized study. Respir Med 1998; 92: 593-6.

7. Akkas Y, Katrancıoglu O, Atasever Akkaş E, Şahin E. A minimal invasive approach in pleural effusions: cystofix catheter. Turk J Clin Lab 2016; 7: 5-9.

8. Tan C, Sedrakyan A, Browne J, Swift S, Treasure T. The evidence on the effectiveness of management of malign pleural effusion: a systematic review. Eur J Cardiothorac Surg 2006; 29: 829-38.

9. Dresler CM, Olak J, Herndon II JE et al. Phase III inter-group study of talc poudrage vs talc slurry sclerosis for malignant pleural effusion. Chest 2005; 127: 909-15.. 